\title{
Experimentally Induced Anachoresis in the Periapical Region After Root Canal Filling
}

\author{
Anacoresis Inducida Experimentalmente en la Región Periapical \\ después de Obturación del Conducto Radicular
}

\author{
Eloi Dezan Jr; Roberto Holland*; Alberto Consolaro*; Francisco Isaak Nicolas Ciesielski ${ }^{* *}$ \\ \& Elerson Gaetti Jardim Jr ${ }^{\text {** }}$
}

DEZAN, E. Jr.; HOLLAND, R.; CONSOLARO, A.; CIESIELSKI, F. I. N. \& JARDIM, E.G. Jr. Experimentally induced anachoresis in the periapical region after root canal filling. Int. J. Odontostomat., 6(1):5-10, 2012.

\begin{abstract}
Anachoresis is the phenomenon through which blood-borne bacteria, dyes, pigments and other materials are attracted and fixed to circumscribed areas of inflammation. This study evaluated the occurrence of anachoresis in the periapical region of dogs submitted to root canal fillings. One hundred and four roots from four dogs were endodontically treated and root canals were filled with zinc-oxide-eugenol cement. Fifty percent were filled up to the dentinocemental junction and the others were overfilled. At 120 days after root canal treatment, experimental bacteremia was induced by intravenous inoculation of 105 CFU Streptococcus pyogenes. The dogs were sacrificed 48 hours and 30 days after the bacteremia. Culture and DNA amplification by PCR revealed the presence of the inoculated bacteria just in periapical tissues of dogs sacrificed 48 hours after bacteremia and not in animals sacrificed after 30 days. AP-PCR fingerprints of recovered colonies of $S$. pyogenes and the presence of genetic markers of resistance to antimicrobials were similar to the inoculated strain. Endodontically treated periapices seemed to be prone to the occurrence of anachoresis and there was no relationship between the phenomenon and the level of root canal filling.
\end{abstract}

KEY WORDS: Anachoresis, bacteria, bacteremia, root canal treatment.

\section{INTRODUCTION}

Bacteria are the main etiologic agents of pulp and periapical pathologies and dental caries and gingival crevice are the main sources of contamination of the pulp tissue and apical periodontal tissues (Lin et al., 2007; Nishiyama et al., 2008; Sakamoto et al., 2008). However, there is also the hematogenic via, in which the bacteria may reach the pulp tissue through the bloodstream during bacteremia (Gomes et al., 2004; Nair, 2004). Bacteremia may occur at several periods; microorganisms are usually eliminated from the bloodstream after 10 to 30 minutes (Hirakata et al., 1993), and the presence of bacteria in blood does not cause problems to the organism if it is able to eliminate them by different immune mechanisms.

Microorganisms may cross the blood vessel walls when the initial immune defense fails, and then they may be destroyed by phagocytosis, plasma enzymes, antibodies and complement (Bender \& Bender, 2003). The bacteria may also be prevented by the physical barrier represented by the blood vessel walls, whose fenestrations are small, thus impairing their penetration into tissues.

This process through which circulating bacteria, pigments, metallic substances, foreign proteins and other materials are fixated to areas of inflammation is called anachoresis (Robinson \& Boling, 1941). Anachoresis is not widely addressed in dental clinics and clinical investigations, even though evidences of this phenomenon have been experimentally demonstrated (Burke \& Knighton, 1960; Gier \& Mitchell, 1968; Delivanis \& Fan, 1984; Tziafas, 1989; Aboudharam et al., 2000).

\footnotetext{
* Department of Endodontics, Araçatuba Dental School, UNESP - Univ. Estadual Paulista, São Paulo, Brazil.

* Department of Pathology, Bauru Dental School - USP, Bauru/SP, Brazil.

*** Department of Pathology and Clinical Propaedeutics, Araçatuba Dental School, UNESP-Univ. Estadual Paulista, Araçatuba, SP, Brazil.
} 
In recent years, significant attention has been dedicated to the destiny of blood borne microorganisms and its clinical implication. Thus, the present study aimed to evaluate the occurrence of anachoresis in the periapical region of dog teeth with root canals obturated at different levels in the influence of time in the survival of the microorganisms in the periapical tissues after bacteremia.

\section{MATERIAL AND METHOD}

Experimental design. The study samples were composed of 32 roots of 4 dogs. After general anesthesia, a rubber dam was placed and the operative field was disinfected and antisepsis of tooth enamel was performed. Access to the root canal system was gained with sterile burs. The root canals were instrumented up to Kerr file n. 40 with step-back preparation up to $\mathrm{H}$ file $\mathrm{n}$. 60 and irrigation with $1 \%$ sodium hypochlorite. After completion of biomechanical preparation, the apical foramen was flared with a Kerr file n. 20 , at $1.5 \mathrm{~mm}$ beyond the working length. The root canals were obturated by the lateral condensation technique with zinc oxide-eugenol cement. Half of the root canals were obturated at the limit of preparation and the other half was overfilled with gutta-percha and zinc-oxide-eugenol cement at $1 \mathrm{~mm}$ beyond the working length. After obturation, coronal openings were restored with silver amalgam.

Induction of anachoresis. Experimental bacteremia was induced at 120 days after endodontic treatment using Streptococcus pyogenes FOA-0307 (106 CFU in PBS), which was applied by intravenous injection. The tested $S$. pyogenes strain had genetic markers of antimicrobial resistance to penicillin G, erythromycin and tetracycline and was highly sensitive to cefoxitin, as demonstrated by drug dilution in agar.The experimental animals were killed by intravenous anesthetic overdose at 48 hours and 32 days after inoculation of the test microorganism. Tissue specimens were removed for microscopic analysis, culturing and detection of inoculated microorganism by PCR.

Recovery of inoculated microorganisms. Eight roots from each period were submitted to microbiological analysis. The fragments comprised a $5-\mathrm{mm}$ apical portion and mineralized or non-mineralized adjacent periodontal tissues and were lightly macerated and stored in flasks containing $3 \mathrm{ml}$ of VGMA III (Möller, 1966). In the laboratory, aliquots of VMGA III were submitted to serial 10 fold dilutions and were plated on tryptic soy agar (Difco) supplemented with yeast extract $(0.5 \%)$ and $5 \%$ horse blood, and incubated in candle jars, at $370 \mathrm{C}$, for 3 days. Pure cultures were obtained and the isolates were subjected to morphocellular and morphocolonial analyses, respiratory test and catalase assay. This was followed by identification of the isolates at the species level, using commercial kits (BioMérieux SA, Marcy-l’Etoile, France).

\section{Confirmation of the identity of recovered microorganisms.}

Pattern of susceptibility to Antimicrobials and genetic profile using arbitrarily primed PCR. To check if the recovered microorganism corresponded to the microorganism previously inoculated by intravenous injection, isolates identified as S. pyogenes were submitted to genetic analysis using AP-PCR and determination of patterns of susceptibility to antimicrobial agents, since the susceptibility of the inoculated microorganism (S. pyogenes FOA-0307) was known. In the tests of susceptibility to cefoxitin (Merck Sharp \& Dohme, São Paulo, SP, Brazil), erythromycin and penicillin G (Fontoura-Wyeth S.A., São Paulo, Brazil), and tetracycline (Forchemicals Ltda, Guarulhos, SP, Brazil). Bacterial inoculum was standardized in 105 cells/ spot and transferred to the Petri dishes containing the antimicrobials and the control plates (without drugs) using a Steer's replicator (Cefar Ltda, São Paulo, SP, Brazil). The minimum inhibitory concentration (MIC) was defined as the smallest concentration of the drug able to completely inhibit the bacterial growth. The breakpoints used for interpretation were those recommended by the CLSI. Antimicrobials were tested in concentrations that ranged from $0.06 \mu \mathrm{g} / \mathrm{ml}$ to 256 $\mu \mathrm{g} / \mathrm{ml}$. The tests were carried out by agar dilution method and the culture medium was Mueller-Hinton agar supplemented with $5 \%$ horse blood.

Presence of genetic markers of antimicrobial resistance. The strains were evaluated by single PCR tests for the presence of genetic determinants associated with resistance to erythromycin and tetracycline. Briefly, $200 \mu \mathrm{l}$ of a fresh culture of the isolates cultivated overnight in Tryptic soy broth (Difco) were submitted to extraction of DNA. The bacterial cells were washed three times in $1.5 \mathrm{ml}$ of ultra-pure Milli $\mathrm{Q}$ water by centrifuging at $8,000 \times \mathrm{g}$ for $5 \mathrm{~min}$. and DNA extraction and purification was done using QIAamp 
DNA mini kit (Qlagen, Hilden, Germany) according to the manufacturer's instructions. The sets of primers used for detection of antimicrobial resistance genes are indicated in Table 1. For detection of erythromycin resistance gene (ermA), the reaction mixtures, in final volumes of $25 \mu \mathrm{l}, 2 \mathrm{mM} \mathrm{MgCl} 2$, dNTP (0.2 mM each), primers $(0.5 \mu \mathrm{M}$ each), Taq DNA polymerase $(0.5 \mathrm{U})$, reaction buffer $(10 \mathrm{mM})$, and $1 \mu \mathrm{l}$ of DNA extract, which was used as the template. The reaction mixtures for detection of tetracycline resistance gene (tetM) contained $20 \mathrm{mM}$ Tris- $\mathrm{HCl}(\mathrm{pH} 8.4), 50 \mathrm{mM} \mathrm{KCl}, 3 \mathrm{mM}$ $\mathrm{MgCl} 2$, dNTP $(0.2 \mathrm{mM}), 0.5 \mathrm{mM}$ each primer, $2.5 \mathrm{U}$ of Taq DNA polymerase, and $5 \mu$ of DNA template. Conditions for amplification of the erm(A), and tet(M) genes were as follows: initial denaturation at $94^{\circ} \mathrm{C}$ for $4 \mathrm{~min}$, followed by 35 cycles at $94^{\circ} \mathrm{C}$ for $1 \mathrm{~min}$, primer annealing at $50^{\circ} \mathrm{C}$ for $1 \mathrm{~min}$, and extension at $72^{\circ} \mathrm{C}$ for $1 \mathrm{~min}$, with a final elongation step at $72^{\circ} \mathrm{C}$ for $5 \mathrm{~min}$. (Robinson et al., 2006)

Genetic analysis of the recovered microorganisms by AP-PCR. Genetic comparisons between $S$. pyogenes FOA-0307 and the strains recovered from dogs were performed through AP-PCR using OPA-03 and OPA-05 primers.

Amplifications were carried out using final volumes of $25 \mu \mathrm{L}$, containing 1X PCR buffer, $50 \mathrm{mM}$ $\mathrm{MgCl} 2$, dNTP $(0.2 \mathrm{mM}), 0.4 \mu \mathrm{mol} / \mathrm{L}$ OPA primer, $0.5 \mathrm{U}$ Platinum Taq DNA polymerase (Invitrogen São Paulo, Brazil) and 5ng DNA. The primers were used for genotyping based on the better discriminatory power observed in the pilot study. Amplification was performed in a DNA thermocycler (GeneAmp PCR system 9700, Perkin-Elmer Applied Biosystems, Branchburg, N.J.) at $940 \mathrm{C}$ for $5 \mathrm{~min}$, followed by 35 cycles of $94 \mathrm{oC}$ for $1 \mathrm{~min}, 42 \mathrm{oC}$ for $2 \mathrm{~min}, 72 \mathrm{oC}$ for $2 \mathrm{~min}$, then at $72 \mathrm{oC}$ for $10 \mathrm{~min}$ to allow the completion of DNA extension. A negative control without a DNA template was included in each AP-PCR run. Reference strains $S$. pyogenes ATCC 700294 was included.

In all PCR and AP-PCR assays, $20 \mu \mathrm{l}$ of the PCR products were analyzed by $1 \%$ agarose gel electrophoresis performed at $70 \mathrm{~V}$ for $2.5 \mathrm{~h}$, stained with $0.5 \mu \mathrm{g} / \mathrm{mL}$ of ethidium bromide, and photographed under a UV transilluminator using a Digital Kodak Science 120 system. A DNA ladder digest of $1 \mathrm{~kb}$ (Invitrogen, São Paulo, SP, Brazil) was used as a molecular weight marker. Individual fingerprints of each recovered $S$. pyogenes and of the strain initially inoculated were compared using a molecular weight search stringency of $\pm 5 \%$ and a " 1 :1" band match restriction. The program designated as a match or as no match.

\section{RESULTS AND DISCUSSION}

The test microorganism was recovered from the two experimental animals at 48 hours after inoculation. Table I presents the minimum inhibitory concentrations of the 5 drugs investigated for the microorganism inoculated in the experimental animals and recovered after $48 \mathrm{~h}$. The susceptibility tests and other biochemical-physiological characteristics of the microorganism recovered from the periapical region suggest that it is identical to that inoculated by intravenous injection.

At the 48-h period, the presence of contaminating microorganisms was mild and associated with manipulation of specimens for microbiological processing or establishment of exogenous microorganisms.

Table I. Minimum inhibitory concentration (MIC) for the S. pyogenes strain inoculated in experimental animals and recovered after 48 hours.

\begin{tabular}{lcc}
\hline \multirow{2}{*}{ Antimicrobial agent } & \multicolumn{2}{c}{ MIC $(\mu \mathrm{g} / \mathrm{ml})$} \\
\hline Cefoxitin (Cf) & $0,5(\mathrm{~S})^{1}$ & Recovered S. pyogenes \\
Erythromycin (Er) & $128(\mathrm{R})^{2}$ & $0,25(\mathrm{~S})$ \\
Penicillin G (Pe) & $64(\mathrm{R})$ & $34(\mathrm{R})$ \\
Tetracycline (Te) & $32(\mathrm{R})$ & $32(\mathrm{R})$ \\
\hline
\end{tabular}

Breakpoints adopted* (mg/ml): Cf, 32; Er, 16; Pe, 1; Te, $8 . \quad 1(\mathrm{~S})$ susceptible $2(\mathrm{R})$ resistant 
In one sample of periapical tissue, the test bacteria were present at 103-104 (Table II). One animal presented the test bacteria and also other microorganisms, yet at mild levels. In the other animal, the test bacteria were present as monoinfection. The test microorganism could not be recovered from the periapical region in animals killed at 32 days after experimental inoculation. Contamination of the periapical region was largely increased; analysis of the cellular morphology of these isolates revealed the presence of a mixed microbiota with many Grampositive cocci and scarce Gram-negative rods. None of the Gram-positive cocci isolated presented the phenotypic characteristics of the test microorganism inoculated and thus they were discarded.

Utilization of microorganisms with markers of resistance to antimicrobials in investigations of virulence or ecological studies in animals is useful in microbiology (Holt et al., 1994). Investigations on in vitro microbial adhesion, experimental infection and anachoresis are established methodologies (Csernyei, 1939; Gibbons \& Van Houte, 1971; Hirakata et al.) that have been employed for the last 60 years. It is unlikely that $S$. pyogenes isolates of the normal or supplementary microbiota of dogs may present the same susceptibility of the test strain inoculated, since this presented multiple resistance. However, to minimize this possibility, the minimum inhibitory concentrations (MIC) of different drugs for this strain was established before inoculation in the animal model and after recovery (Table I), for investigation of resistance or susceptibility, both qualitatively and quantitatively. On the other hand, it is known that there are several synergistic interactions between microbial species in the oral cavity and other habitats. Therefore, the lack of a typical endodontic microbiota may have impaired the establishment of the inoculated microorganism, which would give rise to monoinfection.

The culture sensitivity for detection of microorganisms in clinical samples should also be considered. The strain of Streptococcus pyogenes used in the tests was isolated from tonsillitis and may not have produced a significant infection in the periapical region of some treated teeth; also, it may not have reached the detection threshold of the method, which is not well established for Endodontics. The environmental conditions in the periapical region may not have been favorable for microbial proliferation and recovery, impaired by laboratory manipulation of specimens.

Microbial adhesion to the periapical tissues may have impaired isolation of bacteria, even after maceration of the periapical region of teeth and utilization of a vortex (flask shaker) for bacterial dispersion. Therefore, future studies might employ agents such as the Tween 80 to reduce the bacterial hydrophobicity and consequently the adhesion to the host, thus enhancing isolation of the target microorganism. However, due to manipulation of tissue specimens during removal, transportation and maceration, surfactants were not used, since they might also reduce the viability of some microbial cells (Block, 1991). The presence of other microbial groups in animals killed after 32 days may indicate not only contamination during removal of specimens, but also dissemination of oral and intestinal microorganisms to the periapical region due to bacteremia and anachoresis, as suggested by Allard \& Strömberg (1979).

Luz Centeles (1995) mentioned that chronic manifestations of osteomyelitis have been addressed in bacteriological studies, yet most specimens do not present bacteria. This does not mean that bacteria are not present in the bone tissue; however, their density might be low and they might be hardly detected in bacteriological specimens. They might also be organized on the inner bone surfaces and irregularities of the bone structure such as Howship lacunae and cementoplasts (Ribeiro \& Consolaro, 2000). According to Bramanti et al. (1993), pathogenic microorganisms

Table II. Presence of positivity of S. pyogenes in cultures of roots according to the experimental period.

\begin{tabular}{ccc}
\hline $\begin{array}{c}\text { Time after } \\
\text { bacteremia }\end{array}$ & Roots analyzed & Presence of S. pyogenes \\
\hline $48 \mathrm{~h}$ & 8 & $\mathrm{~N}(\%)$ \\
$32 \mathrm{~d}$ & 8 & $4(50.0)$ \\
& & $0(0.0)$
\end{tabular}

* this number corresponds to 2 roots in each experimental animal 
are subject to intensive environmental and tissue stress during the development of infection, and the expression of bacterial virulence is responsible for colonization of new environments, damage to the host and evasion of its defenses (Slots \& Genco, 1984), being closely associated with these environmental factors. Therefore, the lack of recovery of test microorganisms in animals killed at 32 days after experimental inoculation does not necessarily imply that it was not present; rather, it may have been influenced by the association of stress posed by host-related factors and deleterious effects of laboratory processing, achievement and transportation of tissue specimens. This highlights the importance of methodologies that do not depend on microbial viability, such as PCR (Polymerase Chain Reaction), which might have been employed.

In summary, the occurrence of anachoresis explains clinical situations in which there would be no possibility of bacterial contamination of the pulp or periapical region, yet with establishment of an inflammatory process with significant postoperative symptomatology. Similarly, the occurrence of anachoresis may explain the etiopathogenesis of ca- ses with chronic periapical lesions in teeth without periodontal disease, restorations, fractures and history of dental trauma. In these cases, pulp infarction due to rupture of the neurovascular bundle would not be enough to give rise to a large chronic periapical lesion and would not explain the occurrence of recrudescence, including formation of purulent exudate. Investigation of the possibility of anachoresis in the periapical region after endodontic treatment induces further thinking on the sentence "what is removed from the root canal is more important than what is applied". Residual periapical inflammation due to the irritating potential of the material, even if it is low, is also important, especially in closer contact with the apical periodontal tissues, as observed when the root canal is obturated at the limit or overfilled. The occurrence of anachoresis explains these occasional situations of idiopathic recrudescence of chronic lesions even in cases of vital pulp therapy. However, this phenomenon (anachoresis) should be considered occasional, since these problems are not frequent in Endodontics, possibly because of the small volume of blood flow in the jaws per minute, especially in dental pulps with arborescent distribution of vessels.

DEZAN, E. Jr.; HOLLAND, R.; CONSOLARO, A.; CIESIELSKI, F. I. N. \& JARDIM, E.G. Jr. Anacoresis inducida experimentalmente en la región periapical después de obturación del conducto radicular. Int. J. Odontostomat., 6(1):5-10, 2012.

RESUMEN: Anacoresis es el fenómeno por el cual las bacterias transmitidas por la sangre, colorantes, pigmentos y otros materiales se atraen y se fija a zonas circunscritas de la inflamación. Este estudio evaluó la incidencia de anacoresis en la región periapical de los perros presentados a raíz de los rellenos del canal. Un total de ciento cuatro raíces de cuatro perros fueron tratados con endodoncia y tratamientos de conducto se rellena con cemento de óxido de zinc-eugenol. El cincuenta por ciento estaban llenos hasta el cruce dentinocemental y los otros se llene en exceso. A los 120 días después del tratamiento de conducto radicular, bacteriemia experimental fue inducida por la inoculación intravenosa de 105 UFC por Streptococcus pyogenes. Los perros fueron sacrificados 48 horas y 30 días después de la bacteriemia. La cultura y la amplificación del ADN por PCR reveló la presencia de las bacterias inoculadas sólo en los tejidos periapicales de los perros sacrificados 48 horas después de la bacteriemia y no en los animales sacrificados después de 30 días. AP-PCR huellas dactilares de las colonias recuperadas de $\mathrm{S}$. pyogenes y la presencia de marcadores genéticos de resistencia a los antimicrobianos fueron similares a la cepa inoculada. Periápices endodonciados parecía ser propensos a la ocurrencia de anacoresis y no había ninguna relación entre el fenómeno y el nivel de llenado del conducto radicular.

PALABRAS CLAVE: Anacoresis, bacterias, bacteriemia, tratamiento de conducto radicular

\section{REFERENCES}

Aboudharam, G.; Lascola, B.; Raoult, D. \& Drancourt, M. Detection of Coxiella burnetti DNA in dental pulp during experimental bacteremia. Microb. Pathog., 28(4):249-54, 2000.

Allard, U. \& Strömberg, T. Inflammatory reaction in the apical area of pulpectomized and sterile root canals in dogs. Oral Surg. Oral Med. Oral Pathol., 48(5):463-6, 1979.
Bender, I. B. \& Bender, A. B. Diabetes mellitus and the dental pulp. J. Endod., 29(6):383-9, 2003.

Block, S. S. Disinfection, sterilization and preservation. $4^{\text {th }}$ ed. Lea \& Febiger, Philadelphia, 1991.

Bramanti, T. E.; Holt, S. C.; Ebersole, J. L. \& Van Dyke, T. Regulation of Porphyromonas gingivalis virulence: hemin 
DEZAN, E. Jr.; HOLLAND, R.; CONSOLARO, A.; CIESIELSKI, F. I. N. \& JARDIM, E.G. Jr. Experimentally induced anachoresis in the periapical region after root canal filling. Int. J. Odontostomat., 6(1):5-10, 2012.

limitation effects on the outer membrane protein (OMP) expression and biological activity. J. Periodont. Res., 28:464-6, 1993.

Burke, G.W. \& Knighton, H. T. The localization of microorganisms in inflamed dental pulps of rats following bacteremia. J. Dent. Res.; 39(2):205-14, 1960.

Csernyei, J. Anacoric effect of chronic periapical inflammations. J. Dent. Res., 18:527-31, 1939.

Delivanis, P. D. \& Fan, V. S. The localization of blood-borne bacteria in instrumented unfilled and overinstrumented canals. J. Endod., 10(11):521-4, 1984.

Gibbons, R. F. \& Van Houte, F. Selective bacterial adherence to oral epithelial surfaces and its role as an ecological determinant. Infect. Immun., 3:567-73, 1971.

Gier, R. E. \& Mitchell, D. F. Anachoretic effect of pulpitis. J. Dent. Res.; 47(4):564-70, 1968.

Gomes, B. P.; Pinheiro, E. T.; Gadê-Neto, C. R.; Sousa, E. L.; Ferraz, C. C.; Zaia, A. A.; Teixeira, F. B. \& SouzaFilho, F. J. Microbiological examination of infected dental root canals. Oral Microbiol. Immunol., 19:71-76, 2004.

Hirakata, Y.; Katu, M.; Furuya, N.; Matsumoto, T.; Tateda, K.; Tomono, K. \& Yamaguchi, K. Effect of clearance of bacteria from the blood on the development of systemic bacteremia in mice. J. Med. Microbiol., 38(5):337-44, 1993.

Holt, J. G.; Krieg, N. R.; Sneath, P. H. A.; Staley, J. T.; Williams,S.T. Bergey's manual of determinative bacteriology. $9^{\text {th }}$ ed. Williams \& Wilkins, Baltimore, 1994.

Lin, S.; Sela, G. \& Sprecher, H. Periopathogenic bacteria in persistent periapical lesions: an in vivo prospective study. J. Periodontology, 78:905-8, 2007.

Luz Centeles, G. Bases microbiológicas de la efermedad endodóntica y procesos relacionados. In: Liébana Ureña, J. Microbiologia oral. McGraw-Hill, Madrid, 1995. pp.493510.

Möller, A. J. Microbial examination of root canals and periapical tissues of human teeth. Odontol. Tidskr., 74: 1-38, 1966.

Nair, P. N. Pathogenesis of apical periodontitis and the causes of endodontic failures. Crit. Rev. Oral Biol. Med., 15(6):348-81, 2004.

Nishiyama, S. A.; Nakano, V.; Velásquez-Melendez, G. \& Avila-Campos, M. J. Occurrence of herpes simplex virus 1 and three periodontal bacteria in patients with chronic periodontitis and necrotic pulp. Can. J. Microbiol., 54:326-30, 2008.
Ribeiro, F. C. \& Consolaro, A. Distribuição das bactérias nas estruturas mineralizadas de dentes com necrose pulpar e granuloma periapical. Dental Press Bio. Oral, 1(1):1730, 2000.

Robinson, D. A.; Sutcliffe, J. A.; Tewodros, W.; Manoharan, A. \& Bessen, D. E. Evolution and global dissemination of macrolide-resistant group A streptococci. Antimicrob. Agents Chemother., 50:2903-11, 2006.

Robinson, H. G. \& Boling, L. R. The anachoretic effect in pulpitis. I Bacteriologic studies. J. Dent. Assoc., 28(1):268-82, 1941.

Sakamoto, M.; Siqueira, J. F.; Rôça, I. N. \& Benno, Y. Molecular analysis of the root canal microbiota associated with endodontic treatment failures. Oral Microbiol Immunol., 23:275-81, 2008.

Slots, J. \& Genco, R. J. Microbial pathogenicity. Blackpigmented Bacteroides species, Capnocytophaga species, and Actinobacillus actinomycetemcomitans in human periodontal disease: virulence factors in colonization, survival, and tissue destruction. J. Dent. Res., 63:412-21, 1984.

Tziafas, D. Experimental bacterial anachoresis in dog dental pulps capped with calcium hydroxide. J. Endod., 5(12):591-5, 1989.

Correspondence to:

Elerson Gaetti Jardim Júnior

Department of Pathology and Clinical Propaedeutics,

R. José Bonifácio 1193, 16015-050,

Araçatuba, SP,

BRAZIL

Tel. $+55183636-2797$

Fax: +55 18 3636-4125

E-mail: gaettijardim@gmail.com

Received: 25-11-2011

Accepted: 17-02-2012 